\title{
New perspectives on Pieter Bruegel the Elder's journey to Italy (c. 1552-1554/1555)*
}

\section{Bruegel's journey in context: I Fiamminghi and the south}

Pieter Bruegel the Elder (c. 1528-1569) travelled to Italy at a time when journeys to the south were becoming increasingly popular; from the second half of the sixteenth century onwards, the majority of well-established Northern European artists made such a voyage. In Italy they were called Fiamminghi. ${ }^{\text {. }}$ and while some of them travelled out of personal interests, the main reasons were visiting the ruins of classical antiquity and getting acquainted with the works of the Italian masters. Rome was very popular since it combined the best of both worlds and a visit to the Eternal City was often the underlying reason for undertaking such journeys. It is well known that Jan Gossart (I478-I532) travelled to Italy in 1508-1509, accompanying his patron Philip of Burgundy on a diplomatic mission. ${ }^{2}$ After his return to the Netherlands, Gossart played an important pioneering role in introducing the Italian Renaissance idiom in the Low Countries. ${ }^{3}$

Other well-known artists travelling to Italy prior to Bruegel were Jan van Scorel (I495-1562) and his pupil Maarten van Heemskerck (I498-1574). Both painters played a decisive role in the introduction and propagation of the classical in the Low Countries and they copiously integrated Roman architecture and sculpture in their own works based on sketches which were made on the spot. Long after their return to the Netherlands these antique ruins and sculptures proved to be fruitful sources of inspiration for both artists. Contemporary writers elaborately describe the voyages as well as the artists undertaking such journeys to the south. As Vasari stated, most of Bruegel's compatriots travelled to Italy to learn the Italian manner. ${ }^{4}$ In general Pieter Bruegel is not considered one of those sixteenth-century artists who assimilated the Italian influence. On the contrary, he is mostly regarded as one of the artists who stayed true to the so-called vernacular style. Also, the artist seldom integrated specific monuments and sculptures in his work, reminiscent of classical antiquity or the Italian Renaissance. ${ }^{5}$ However, the influence of the artist's journey to the peninsula can hardly be overrated. Bruegel's assimilation of Italian influences has long been misjudged, but nowadays it is generally acknowledged that the artist, albeit in a more subtle manner, is tributary to different aspects of Italian art. ${ }^{6}$ Moreover, it was during his journey that Bruegel developed the unprecedented observing realism that would become a hallmark and one of his greatest artistic qualities. Bruegel manifested himself as a true landscapist and his earliest surviving works exclusively consist of landscape drawings; some of them from nature, others the work of his imagination. Besides revealing details on the master's creation process, a profound analysis of the documentary drawings can provide additional information on the travel circumstances and more specifically on the route followed by the artist. It appears that a thorough examination of these drawings re-evaluates the general premise that the artist travelled through the Alps during his outward journey. Moreover, together with the later paintings and prints that are specifically related to the voyage, Bruegel's route can largely be reconstructed, albeit with certain lacunae. 


\section{Travel conditions and motives}

We know for certain that Bruegel was in Italy in I552-1554. However, it is rather difficult to determine the precise moment at which he left his hometown. The artist joined the local guild of Saint Luke in I55I-1552, and it is most likely that he left Antwerp some months after his registration.7 Bruegel probably ventured south during early spring of I552 since he would have waited the severe winter season to end before departing. Contemporary accounts reveal that voyagers rarely travelled alone since setting out on such a long trip incurred many risks and travelling in group was also a matter of practical and financial considerations. ${ }^{8}$ Moreover, it was much more pleasant to travel in the companionship of compatriots. 9 There has been some speculation on Bruegel's fellow travellers and several authors suggest that the painter and print designer Maarten de Vos (1532-1603) and the sculptor Jacob Jongelinck (1530-1606) were among his companions. ${ }^{10}$ Despite the fact that both De Vos and Jongelinck were in Rome in the early 1550's, the circumstantial evidence does not prove that the artists travelled together. Other authors claim that the famous cartographer and Bruegel's later friend Abraham Ortelius (I527-1598) joined the artist when he left Antwerp. ${ }^{11}$ Although we know that Ortelius visited Italy several years after Bruegel's trip, this statement is also without further proof.

Apart from his general curiosity and eagerness to explore and learn, Bruegel's journey to Italy was also motivated by other factors, including the recent death of his master Pieter Coecke van Aelst (1502-1550). As his apprentice, Bruegel was responsible for the continuation of the workshop together with Coecke's widow, Mayken Verhulst (I5 18-1599). Coecke was a very successful painter who had gone to Italy himself during the 1520 's. ${ }^{12}$ It is plausible that Mayken Verhulst, who would become Bruegel's mother-in-law some twelve years later, encouraged the young artist to go abroad to perfect his art in regard to a successful continuation of Coecke's former workshop. ${ }^{13}$ An additional stimulus for Bruegel's departure can be found in another determining event in his career, namely his collaboration with the print publisher Hieronymus Cock (I518-1570). In his biography of 1604 Karel van Mander wrote: 'He learned art with Pieter Koeck van Aelst [...] From there he went to work at Jeroon Kock's, thereafter travelling to France and hence to Italy.' ${ }^{\text {I4 }}$ Van Mander informs us on the artist's employment in Cock's publishing house and printing workshop Aux quatre vents directly after completing his apprenticeship in Coecke's studio and it is apparent that he was already involved with Cock immediately before his departure to Italy. Although the first results of Bruegel and Cock's collaboration can only be seen after his return to Antwerp in 1554-1555, the scenario that he partially undertook the trip to provide Cock with designs for prints is perfectly plausible. Moreover, the series of the Large Landscapes, published shortly after his return, bear a strong influence of the landscape impressions he must have encountered during the journey. An additional argument for this early collaboration is to be found in the remarkable similarities between Bruegel's early landscapes and several prints published by Cock. As in this period, Cock tried to manifest himself as a cartographer and a successful print publisher, he might have encouraged the young artist to make the journey to provide sketches and designs. ${ }^{15}$

\section{On the road to Italy}

Bruegel's journey is of major importance to our understanding of his initial development as an artist and the impressions during the voyage had an everlasting impact on his oeuvre. This particularly accounts for Bruegel's Alpine experience. The encounter with vast mountainous landscapes was a seemingly inexhaustible source from which he drew inspiration for the rest of his career. Moreover, it is in these early years that he developed the focused realism which is so characteristic of his art. As mentioned before, the meticulous rendering of the observable reality is specifically apparent in the early drawings, which were exactly created in 1552-I554. These drawings provide information on the 
Pieter Bruegel the Elder, Southern Cloister in a Valley, 1552, pen and brown ink, accents in watercolour by a different hand, $18,5 \times 32,6 \mathrm{~cm}$. Staatliche Museen zu Berlin, Kupferstichkabinett, inv. no. KdZ 5537. specific landscapes Bruegel must have seen and as a result, they shed light on his travel route. ${ }^{16}$ The general routes for Fiamminghi travelling to Italy were largely determined by contemporary postal roads, which mostly followed the ancient commercial routes. ${ }^{17}$ Due to a lack of factual evidence the opinions of Bruegel scholars who have studied his voyage differ concerning the exact route the artist must have followed. Nevertheless it is possible to set up a general outline. The hypothesis presented here simply departs from a thorough analysis of Bruegel's hitherto known oeuvre and this visual information is complemented with archival sources. The first work attesting Bruegel's trip concerns a now-lost glue-size cloth painting ('waterverf op doeck') depicting a View of Lyons. It is listed in the inventory of Giulio Clovio (I498-1578) of 1577 as 'Un quadro di Leon di Francia aguazzo di mano di Mro Pietro Brugole ${ }^{18}$ Clovio was a famous Croatian illuminator whom Bruegel probably met in Rome. ${ }^{19}$ The relation between the two artists appears to have been a quite amicable one, inferred from their collaboration and the fact that Clovio had at least four works of Bruegel in his possession..$^{20}$ The inventory provides us a terminus ante quem; since Bruegel must have given the View of Lyons to Clovio before returning back to Antwerp, it can be dated c. 1552-1554. Lyons was an important intermediate stop on the old Via Francigena and contemporary sources attest the popularity of this route amongst the Fiamminghi. ${ }^{21}$ During the early modern period, there were important commercial and intellectual connections between Antwerp and Lyons and contemporary sources attest the presence of several Netherlandish artists in the city. ${ }^{22}$ It is generally assumed that after passing through Lyons, Bruegel continued eastwards crossing the Alps to reach Italy. ${ }^{23}$ However, a thorough analysis of some of his earliest landscape drawings suggests that this is not the case. In my opinion, one drawing even attests Bruegel's presence in the southeast of France, namely in the region Provence-Alpes-Côte d'Azur, which implies a re-evaluation of the initial route followed by the artist. It refutes the premise that he had crossed the Alps during his outward journey.

Southern Cloister in a Valley is one of the earliest known landscape drawings from Bruegel's hand (fig. I). ${ }^{24}$ The original drawing was executed in pen and brown ink and the sheet contains a French watermark. Bruegel signed the work in a rectangular space on the bottom left and also dated it 'i 552 '. Despite the washes added by a later hand,

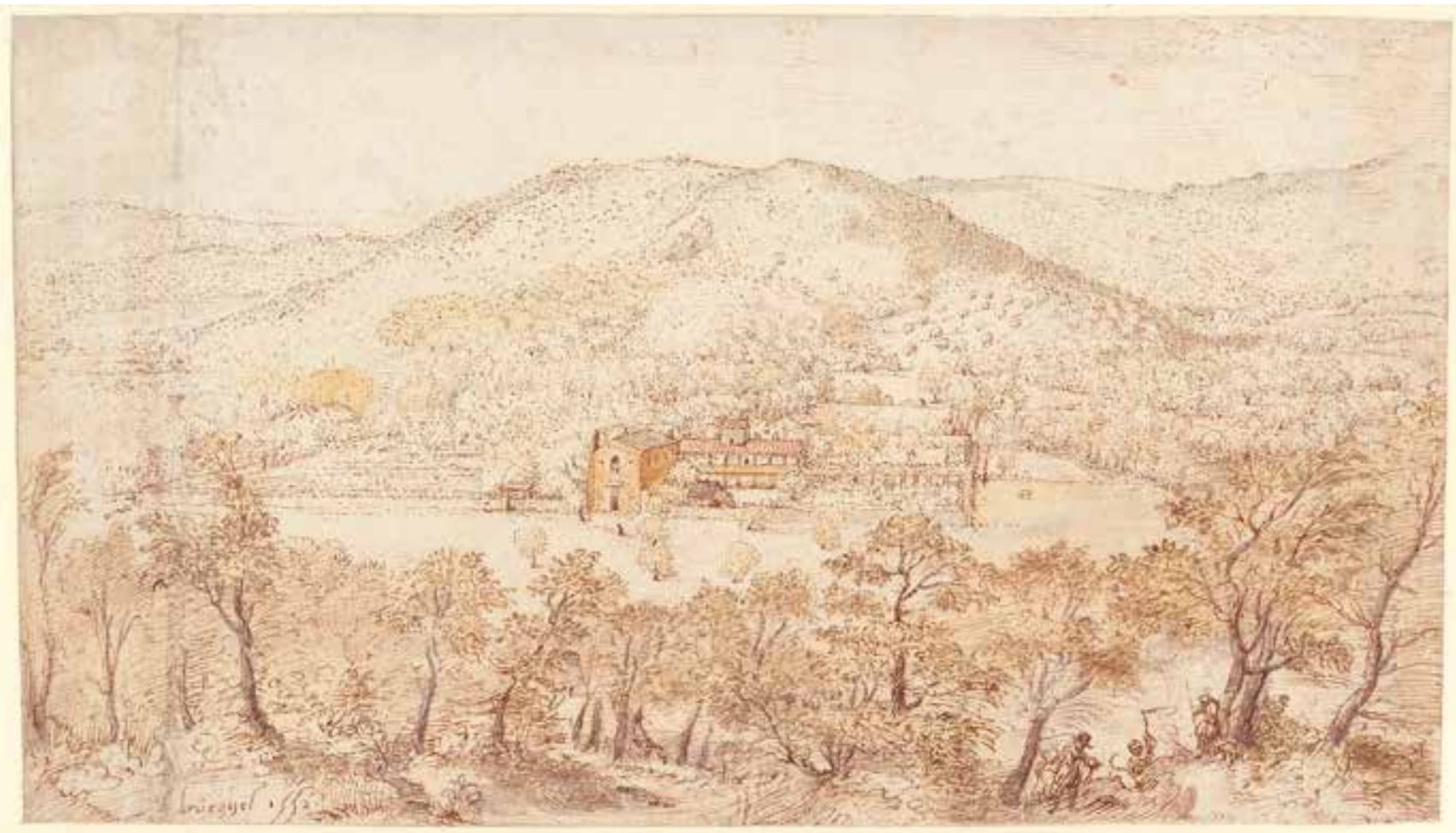


Chapel of Sainte Blaise, Les Baux de Provence. Chapel of Mas, Arles.

Abbey Notre-Dame of Sénanque, Gordes.
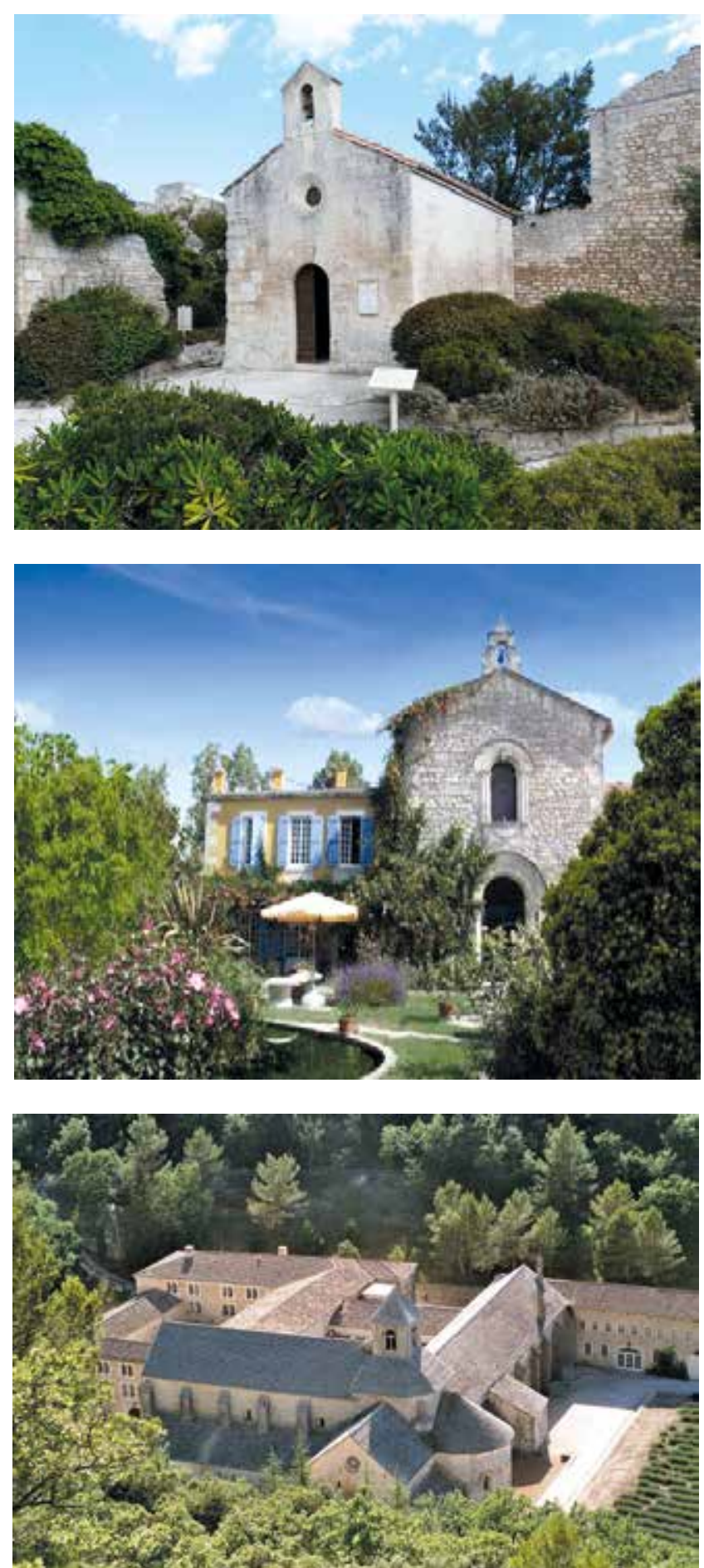

the attribution has never been doubted. He sketched the scene with swift strokes and it is one of the few examples the artist executed outdoors, in situ. ${ }^{25}$ In the centre we see a chapel with an adjacent building with belvedere and enclosed garden. The cloister is embedded in a valley surrounded by a hilly landscape and the building style is distinctly Romanesque. In the foreground at the lower right-hand side we discern a hunting scene which was added later in the studio. Despite the presence of the French watermark, several authors suggest that the drawing was made in Italy, referring to the southern (presumed Italian) character of the architecture. ${ }^{26}$ According to this assumption, Bruegel acquired the sheet in France and brought it to Italy where he executed the drawing. Even more specific, the artist would have made the work in southern Italy or in the inland during his passage along the Italian coast between Naples and Rome. ${ }^{27}$ Others suggest 
that he might have purchased the sheet in Rome..$^{28}$ At first sight the southern Romanesque architectural style seems to confirm the general hypothesis. However, after a thorough investigation of the specific features and a fundamental comparison with iconographical sources, it becomes clear that the architecture is not specifically Italian in nature. Moreover, it actually has a plain Provençal character. There are several examples in the region Provence-Alpes-Côte d'Azur that bear striking resemblances to the architecture and landscape in Bruegel's drawing. The Romanesque chapel strongly resembles the Chapelle Saint Blaise in Les Baux de Provence (between Avignon and Arles) (fig. 2). Other chapels that are stylistically related are the Mas de la Chapelle in Arles (fig. 3 ) and the Chapelle du Hameau de Serres in Carpentras. A similar architectural style is to be found in the famous abbeys of Sénanque (near Gordes, fig. 4) and Silvacane (Bouches-du-Rhône). ${ }^{29}$ Also, the natural scenery in which Bruegel's cloister is embedded, corresponds with the undulating landscapes where the mentioned roman chapels and abbeys are situated. This implies that Bruegel did not necessarily bring the sheet from France to Italy and sketched the scene from an Italian topographical locality. On the contrary, the analysis demonstrates a close correspondence between Bruegel's cloister and Provençal religious buildings. It is most likely that the artist was inspired by the Provençal landscape and based his drawing on a contemporary site..$^{30}$

A possible explanation for Bruegel's presence in the southeast of France can be found in the initial route he and his companions must have followed. They probably passed through this region on their way to Marseille. ${ }^{31}$ The harbour of Marseille (nowadays the Vieux Port, located at the end of the Canebière) is one of the oldest international ports of the Mediterranean Sea ('Massalia'), fulfilling a central role in the trade between the Mediterranean area and the western part of Europe. Throughout the Middle Ages the natural harbour remained one of the busiest ports of France and besides its trading function it was also a popular passage for travellers. ${ }^{32}$ Contemporary travel reports inform us as to how voyagers passed through Marseille on their way to the peninsula. ${ }^{33}$ Moreover, Bruegel's presence in the Provençal region is also suggested by a passage in Edward Norgate's Miniatura or the Art of Limning from 1650: 'Of these many strange and yet beautiful views are to be seene from and about Mont Senis, Launebourg, Novalaise, and about Mont Godardo in Germany, and many other places about Provence, most which have been very well designed after the life by Peter Brugell of Antwerp, and remaine in "stampe" to his great commendation. ${ }^{34}$

In the 1960 's Menzel had already suggested that Bruegel embarked in Marseille to reach the Italian mainland. ${ }^{35}$ There were different ways to do so. Either, one could travel by 'fellucas'; rather small, open barges operating between the different ports along the Ligurian Sea, ${ }^{36}$ or one could opt for a galley directly heading southwards. The latter was a faster mode of transportation which simultaneously offered more comfort. However, contemporary travel accounts reveal that travellers often preferred the 'fellucas' since navigating into the open sea contained considerable risks. ${ }^{37}$ Another option was to continue the trip on land, following the Italian Riviera by foot, carriage or on horseback (fig. II). ${ }^{38}$ Presupposing Bruegel's presence in Marseille, it is probable that he voyaged via the Ligurian coast. There had been strong commercial and artistic ties between the southern Low Countries and the Ligurian area since the fifteenth century and Genoa was a popular destination among Netherlandish artists. ${ }^{39}$ Based on the early date, the characteristic drawing qualities (the drawing was partially made in situ) ${ }^{40}$ and the remarkable resemblances between the Provençal architectural landscape and the representation in Southern Cloister in a Valley, Bruegel's presence in the Provence seems apparent. Considering this presence, it is probable that the artist continued his journey from Marseille, in which case a visit to the Ligurian area seems reasonable. However, until we have further evidence at our disposal, Bruegel's presence in the Ligurian region is merely hypothetical. Nevertheless we do have evidence that confirms Bruegel's presence further south. 
Pieter Bruegel the Elder, View of Reggio Calabria, c. 1560, pen and brown ink, reworked with a brush and grey ink by a different hand, 15,4 x 24,1 cm., Museum Boijmans Van Beuningen, Rotterdam, inv. N 191

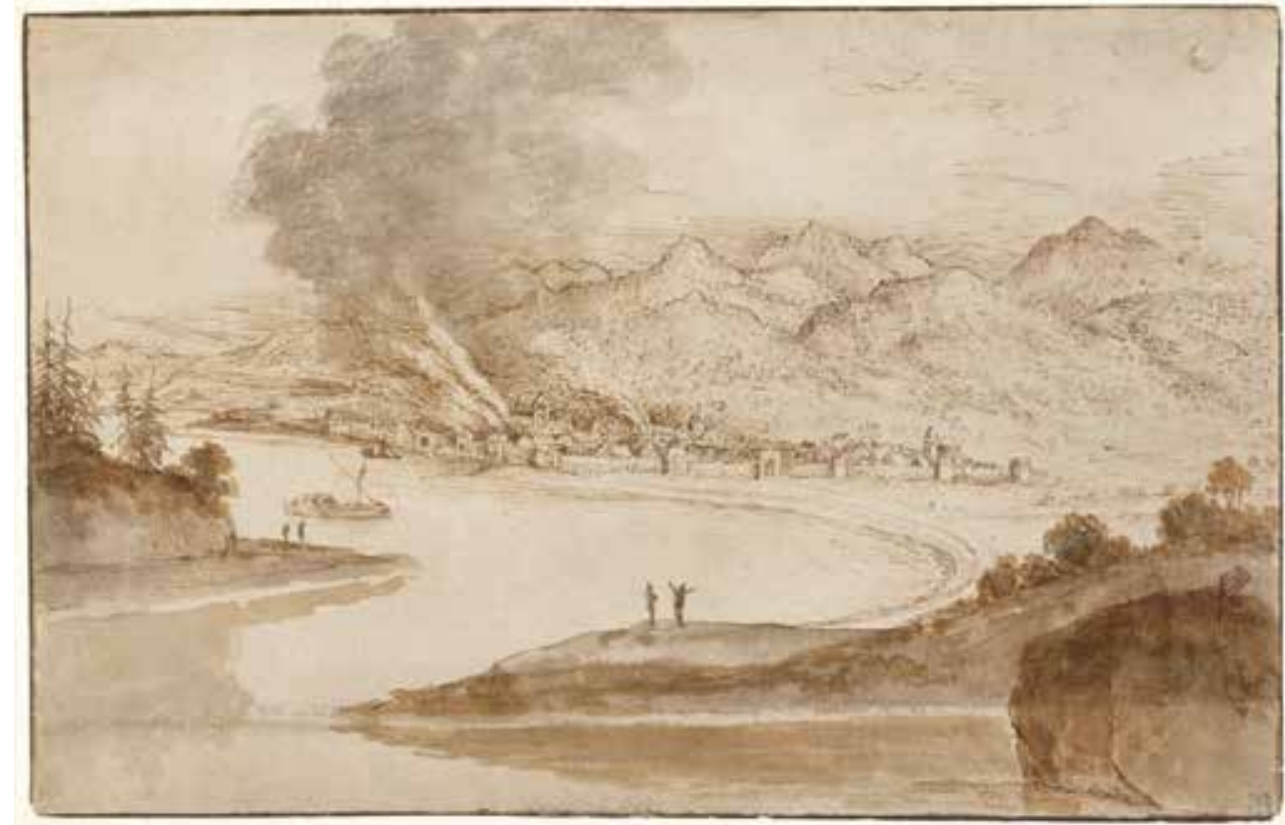

\section{Hitting further south}

A drawing representing a View on Reggio di Calabria suggests the artist visited the southern Italian region (fig. 5). ${ }^{41}$ The city and the adjacent Strait of Messina are rendered from a distant hill and we discern a fierce fire inside the city walls with flames and smoke reaching high into the sky. In the last decades there has been some disagreement on the precise dating of the sheet. Among others, Menzel, Allart and Büttner have suggested an early dating based on the specific scene depicted by Bruegel..$^{42}$ The subject is usually related to an event that took place in I552-1553 when different encounters between Turkish and Italian fleets occurred in the region. ${ }^{43}$ Several times, the Turkish attacks resulted into huge fires. Based on the presumption that Bruegel made the drawing ad vivum, the authors assume he must have been in the region around 1552-1553, consequently dating the drawing c. 1552. Following the assumption that Bruegel was present in Reggio, they conclude that the artist must have used a more rapid form of transportation that allowed him to arrive in the south of Italy as early as 1552 . Since it would not be feasible to make such a long voyage over land in such a short time, the authors concluded that he must have travelled, at least partially, by boat. However, the grounds on which Menzel, Allart as well as Büttner based their hypotheses appear to be incorrect.

Besides the drawing, there is a large print which also depicts the Strait of Messina between Sicily and the Italian mainland (fig. 6). ${ }^{44}$ The print was engraved by Frans Huys and published by Hieronymus Cock and Cornelis van Dalem (I528-1573/1576) in I561. There are some remarkable similarities between Huys' print and Bruegel's drawing of Reggio di Calabria. In fact, the left side of the engraving is an exact reproduction of Bruegel's drawing, albeit in reverse. The drawing appears to be specifically drawn in mirror image, clearly as a preparatory study for a print. ${ }^{45}$ It is hard to imagine that Bruegel would have been drawing landscapes in reverse for an as yet unknown engraver (Frans Huys) and publisher (Hieronymus Cock) to be produced almost a decade later. ${ }^{46}$ In addition, Huys' print is the largest known engraving made after Bruegel's design. Such an undertaking implied financial risks and it is unlikely that he made the design several years before the actual print was published, without knowing if the design would ever be engraved and published. Moreover, the drawing technique is very precise and the details are too abundant for a primary sketch directly made after nature. Nowadays most specialists agree that the drawing View on Reggio Calabria was conceived as a model for Huys' print thus limiting the time frame to c. 1560-156r. In other words, Menzel's, Allart's and Büttner's assumption that Bruegel travelled by boat on his passage to Italy was based 
Frans Huys, after Pieter Bruegel, Battle in the Straits of Messina, 1561, engraving and etching, 43,4 x 71,7 cm. Bibliothèque Nationale de France, Paris, Cc 25

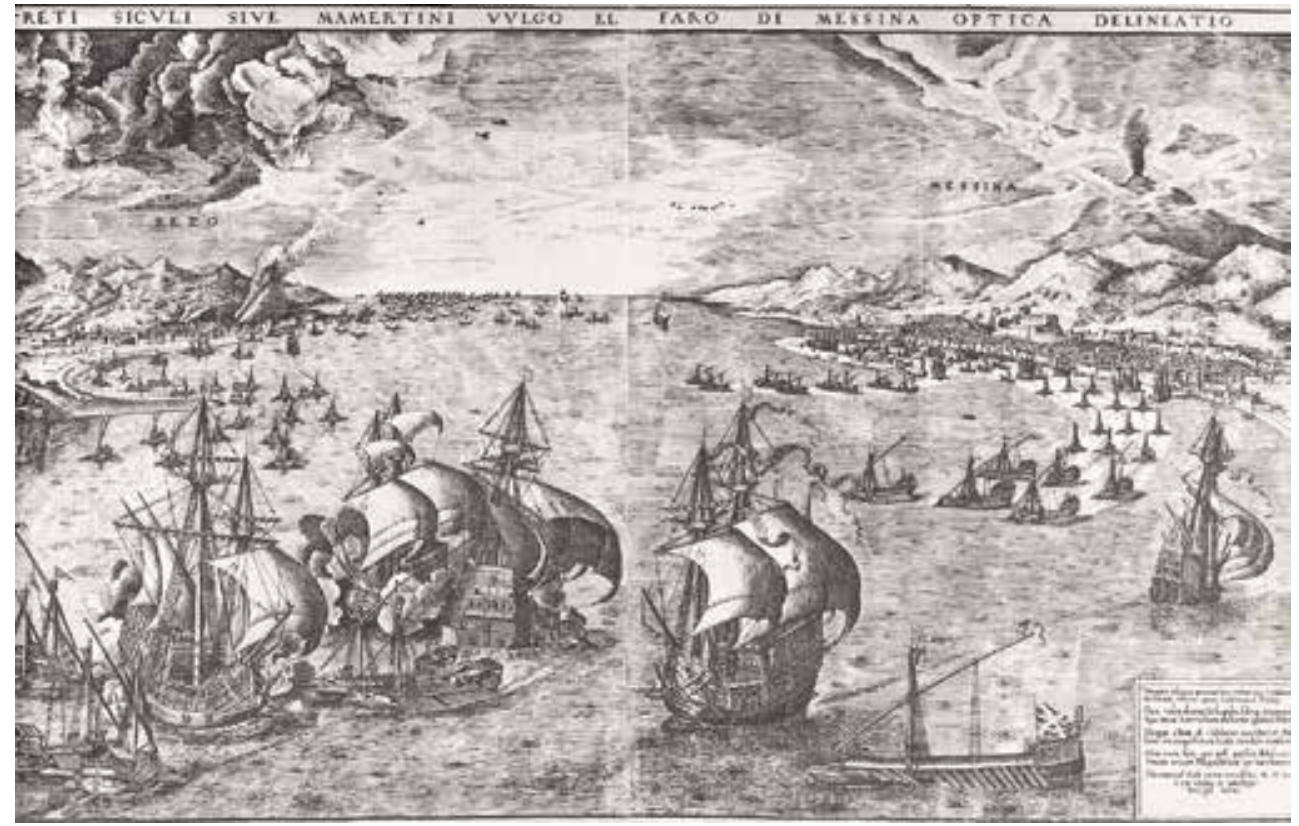

on a mistaken presumption. However, the fact that the print design only originated around 1560 does not necessarily exclude the possibility of Bruegel's presence in the region in $1552-1553$. On the contrary, the preciseness and abundant rendering of details in the drawing suggest that Bruegel made several sketches on the spot and afterwards assembled those in the final version.

An additional indication for the existence of such sketches is provided by a View on Messina by Joris Hoefnagel included in Braun and Hogenberg's Civitates orbis terrarium. ${ }^{47}$ The inscription states that Hoefnagel made the design after a drawing by Bruegel, which confirms the existence of several drawings (and not just one on which the View on Reggio was based) that eventually served to compile the final design for the print which was published by Cock..$^{8}$ Besides the Rotterdam drawing, the engraving Battle in the Strait of Messina and the lost sketches by Bruegel, there is another work which is regularly mentioned regarding the artist's presence in the deep south of Italy. It concerns a painting depicting a Battle in the Bay of Naples, today in the Galleria Doria Pamphilj in Rome. ${ }^{49}$ Due to technical and stylistic shortcomings the attribution to Bruegel is problematic, hence this painting is omitted in the discussion of his itinerary. ${ }^{50}$

\section{Bruegel's stay in the Eternal City}

It is certain that Bruegel's voyage eventually led him to Rome, the epicenter of antique and contemporary art and culture. Rome was a popular travel destination for the Fiamminghi and for some of them a visit to the Eternal City was the ultimate goal of their journey to Italy. They were present in large numbers and often sought out each other's company. ${ }^{\text {si }}$ Several visual sources confirm Bruegel's attendance in the city and he must have arrived there somewhere in 1553-1554. Although no autograph works are known that were made during the artist's stay in Rome, other sources confirm the date. At the end of the century, Simon Novellanus (Simon van den Heuvel or van den Neuvel, active in Germany around 1560-1595) made two etchings that were later published by Hoefnagel.52 Both prints represent landscapes and stylistically they are remarkably similar to Bruegel's early panoramic landscape drawings. ${ }^{53}$ Furthermore, the inscription reveals that Novellanus based his prints on original designs made by Bruegel in Rome in 1553: 'Petrus Bruegel fec: Romae A[nno] I553'. It is likely that these original designs (probably drawings) to which Hoefnagel and Novellanus had access, were signed and bore a similar inscription 
Pieter Bruegel the Elder, View of the Ripa Grande, c. 1553, pen, brown ink, $20,7 \times 28,3 \mathrm{~cm}$. The Duke of Devonshire and the Chatsworth Settlement Trustees, Chatsworth, inv. no. 841

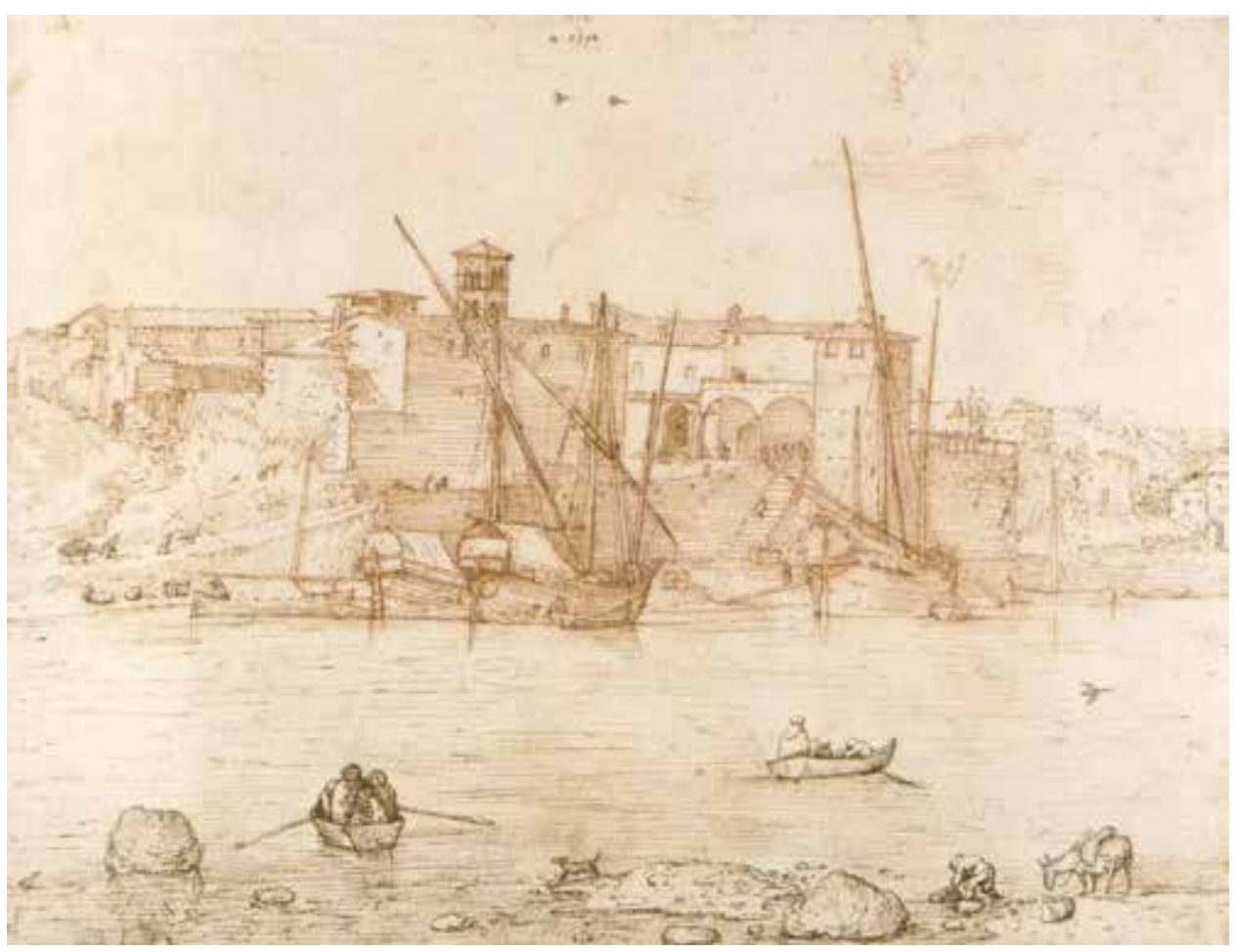

specifying that they were made in Rome in 1553 (e. g. 'ROMAE A: $1553^{\prime}$ ). An additional indication for the artist's presence in Rome is provided by a group of drawings which are largely copies made by Bruegel's sons after originals, with the following annotation: 'Bruegel invent I554 Roma.'s4

A drawing with a View of the Ripa Grande (fig. 7) is the only autograph sheet that actually confirms the artist's presence in Rome. ${ }^{5}$ Although the drawing is undated, until recently it was generally believed that Bruegel executed it during his stay in Rome, consequently dating it c. 1553. However in 2013, in his groundbreaking article on Bruegel's landscape drawings, Manfred Sellink proposes a later dating around 1556. ${ }^{56}$ This is based on the close stylistic and technical correspondence to the drawing Rest on the Flight into Egypt in the Kupferstichkabinett, Berlin. ${ }^{57}$ In spite of this later date it is nevertheless clear that Bruegel based his View of the Ripa Grande on sketches which were made on the spot. During the sixteenth century, the Ripa Grande was Rome's principal harbour for seagoing ships. Bruegel drew the view from the south-east bank of the river looking towards the old custom wharf, the Dogana Vecchia. He used a remarkable low point of view and the frieze-like composition is clearly in the tradition of contemporary Renaissance vedute. It appears to be a truthful rendering of the site and he started with the background, recording the architectural setting and boats in a delicate and precise style. The foreground, in which a more robust draughtsmanship is apparent, was later added.$^{8}$ Apart from the View of the Ripa Grande drawing, another visual source confirms Bruegel's presence in the area of Rome. It concerns a print of which the design is now lost, the View of the Tiber near Tivoli (fig. 8). Tivoli (the ancient Tibur) was situated northeast of Rome and from thereon it was easily accessible through the Via Tiburtina. The print is part of the series of the Large Landscapes, published by Cock after Bruegel's return to Antwerp (I555-1556). The fact that the View on Tivoli is part of this series is rather atypical because it is the only print where an actual site is represented. The others represent imaginary landscapes combining impressions from Bruegel's Alpine experience with standard elements of the Netherlandish landscape tradition. Because of its hilly landscape and famous waterfalls, Tivoli was a popular destination for contemporary Italian tourists. Additionally, foreign tourists wanted to visit the site because of the ruins of the antique city Tibur, which, according to Horace, supposed to have been one of the most beautiful places in the world. ${ }^{59}$ 
Apart from the visual evidence found in the View of the Ripa Grande and the View of Tivoli, two other paintings bear witness to Bruegel's stay in Rome, albeit more indirectly. These involve Bruegel's versions of the Tower of Babel; one in the Kunsthistorisches Museum in Vienna (1563) and the other in the Museum Boijmans Van Beuningen in Rotterdam (c. 1568?). ${ }^{60}$ The Vienna version represents the process of the building of the tower whereas in the latter the construction has been completed. Although the two depictions differ in character, both towers show several remarkable similarities with the Colosseum. Various elements were clearly inspired by the Roman amphitheater such as the general outsight, certain constructional aspects and specific building materials. ${ }^{61}$ Additionally, the artist's attendance in Rome is also confirmed in written sources, such as the inventory of the illuminator Giulio Clovio which confirms the fact that Bruegel and Clovio must have met. It is most likely that this encounter took place in Rome and specialists generally assume it happened in 1553 . That year, Clovio had just returned to Rome after a long period of absence. ${ }^{62}$ Unfortunately, we do not know precisely when Bruegel left Rome but he must have departed there sometime in 1554 because we know that he was back in Antwerp in 1554-I555. Since the series of the Large Landscapes were published from 1555 onwards, Bruegel must have been present in his hometown at least some months earlier.

\section{Bruegel's journey through the Alps}

During the Middle Ages, mountains in general and the Alps in particular, were often regarded as dangerous phenomena that inspired awe. Although this particular perception still persisted during the sixteenth century, the fearful sentiment was gradually altered through a great admiration accompanied with a profound interest in the phenomenon. ${ }^{63}$ It was during this period that the first accounts appeared describing the impressions created in the minds of early modern travelers beholding these impressive natural manifestations. Nowadays it is difficult to grasp the major impact beholding such mountain landscapes must have had on contemporary viewers. It is well known that at some point during his journey, Bruegel crossed the Alps and beheld these undoubtedly overwhelming mountainous landscapes. It is indisputable that these made an everlasting impression on him. In his biography of the artist, Van Mander wrote: 'On his travels he

Joannes and Lucas van Doetecum, View of the Tiber near Tivoli (Prospectus Tyburtinus), c. 1555-56, etching and engraving, $32 \times 42 \mathrm{~cm}$.

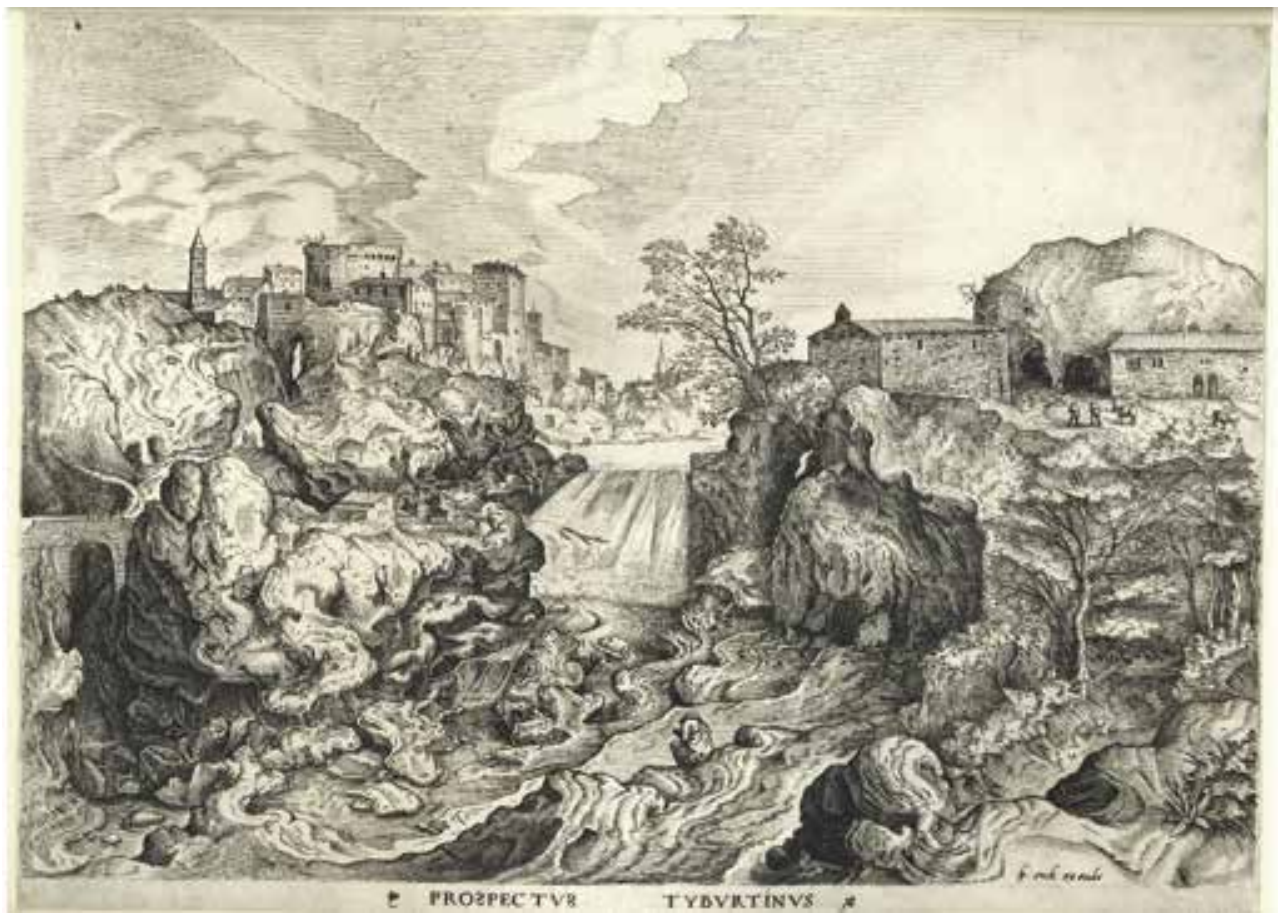


Mountain Landscape, 1553, pen and brown ink, $23.6 \times 34.2 \mathrm{~cm}$., Musée du Louvre, Paris,

Département des Arts

Graphiques, inv. no. 19.728.

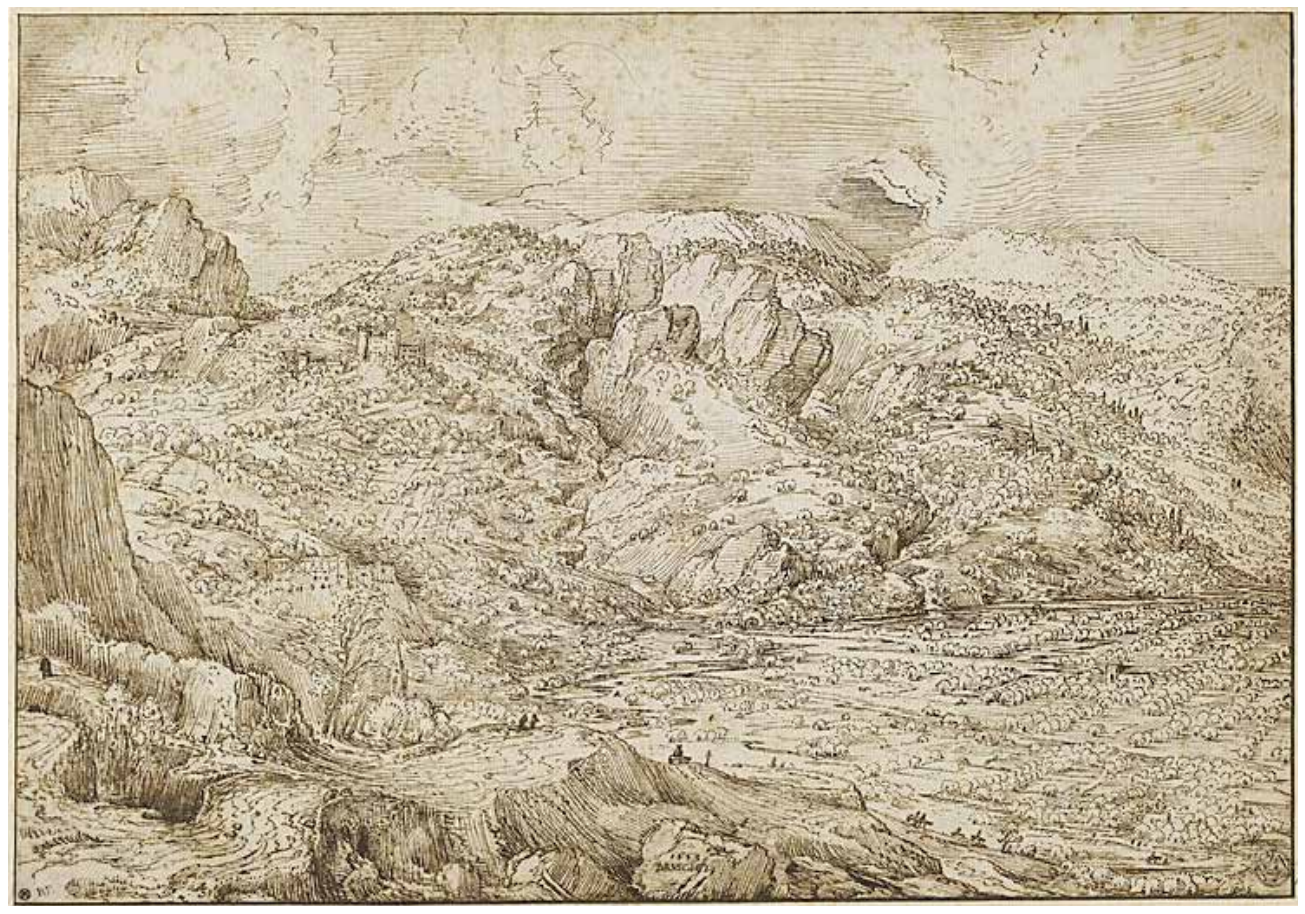

drew many views from life so that it is said that when he was in the Alps he swallowed all those mountains and rocks which, upon returning home, he spat out again onto canvases and panels, so faithfully was he able, in this respect and others, to follow Nature.'64

However, besides Van Mander's passage, the most evident manifestation of these long lasting impressions is apparent in the visual evidence, especially in later works created after his return to Antwerp that were probably based on sketches the artist executed during his voyage. Following a hypothesis advanced by Konrad Oberhuber in 1980-198I, the majority of Bruegel scholars assume the artist crossed the Alps on his way to Italy. ${ }^{65}$ Oberhuber based his assumption on a group of some twenty closely related drawings depicting Alpine landscapes, which were long considered as a testimony to Bruegel's encounter with the Alps and believed to be the sketches mentioned by Van Mander. In his articles Oberhuber stated he wanted to undo the myth that the artist's travel through the Alps took place during Bruegel's home passage. This so-called 'myth' was first put forward by Henry Hymans in the second half of the nineteenth century. ${ }^{66}$ Hymans based his premise on Van Mander's account that tells us that Bruegel travelled through France to get to Italy ${ }^{67}$ In several of these Alpine drawings, the author recognized Austrian and Swiss sites. Combined with the passage in Van Mander's Schilder-boeck, this identification led Hymans to suggest that Bruegel crossed the Alps during his return journey and he dated the drawings c. 1554-1555.

During the following century and two decades, specialists generally accepted Hymans hypothesis. Nevertheless, since 1980 Oberhuber's findings have dominated Bruegel research. However, since Hans Mielke's publications in 1991, this group of unsigned drawings is no longer considered as autograph. ${ }^{68}$ Mielke's deattribution was highly controversial since these Alpine drawings were considered core works by the artist and they were regarded as the sketches mentioned by Van Mander. The author discovered that the watermark on two drawings was only found on paper dating from the mid-I $580^{\circ}$ 's through the mid-seventeenth century implying that the earliest possible date would be some twenty years after Bruegel's death in 1569 . Considering the great stylistic and thematic coherence between the drawings, this conclusion was also applicable to the other drawings in the group. Consequently, Mielke proposed a subtraction of the entire group from Bruegel's oeuvre and an attribution to Roelandt Savery. Also, Roelandt's elder brother, Jacob, has been suggested as a possible author. ${ }^{69}$ In the $200 \mathrm{I}$ exhibition catalogue 
The Conversion of Saul, oil on panel, $108 \times 156 \mathrm{~cm}, 1567$. Kunsthistorisches Museum, Vienna, inv. no. 3690.

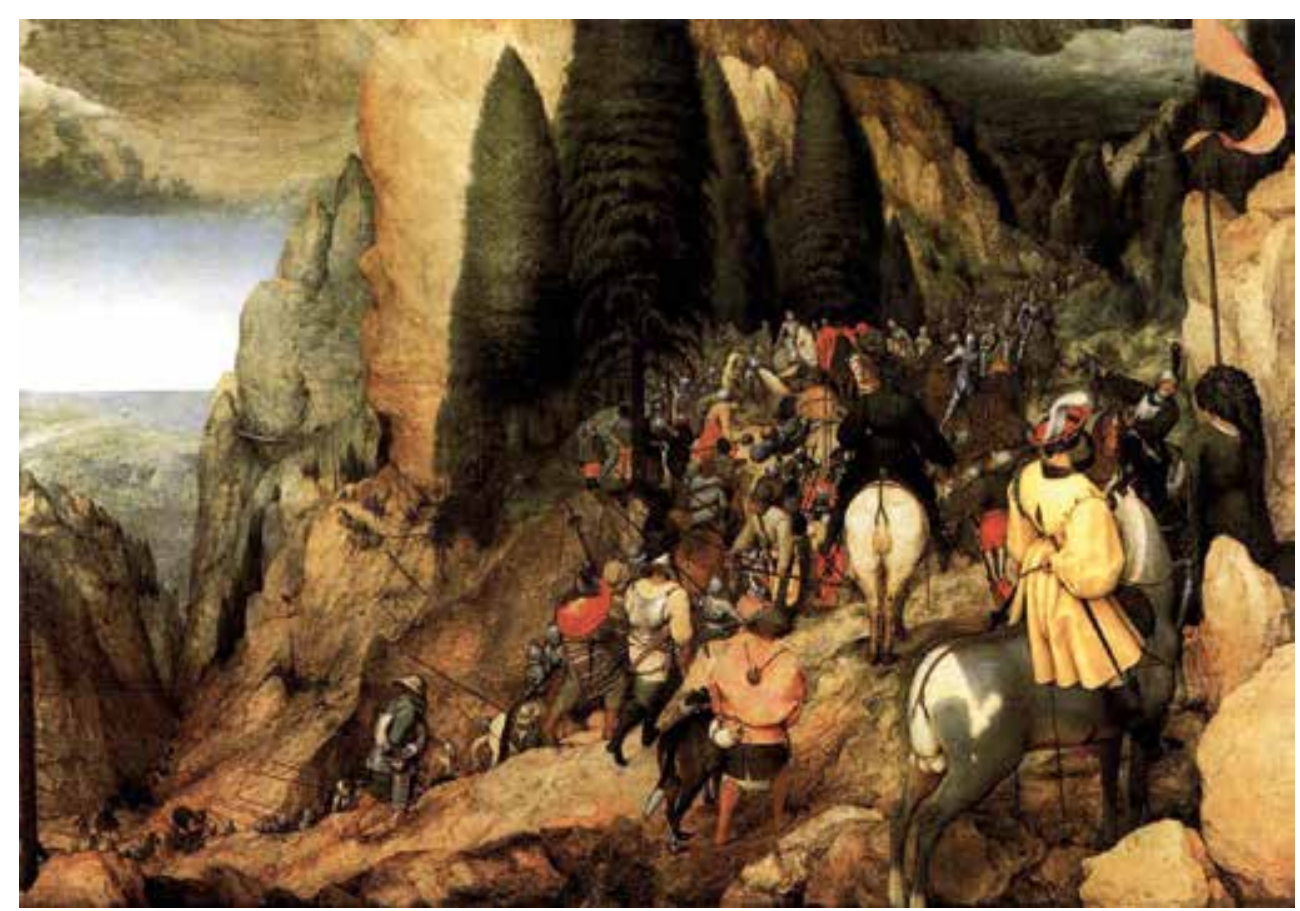

on Bruegel's drawings and prints, Nadine Orenstein suggested the appropriate name 'Master of the Mountain Landscape' be given to this anonymous artist. Since then, no one has yet succeeded to unravel the identity of this unidentified master. What is of importance here is that Oberhuber's proposition of Bruegel's passage through the Alps in I55I-I552 was thus based on non-autograph material. It is remarkable that since then, the author's hypothesis has seldom been questioned and until today most scholars still assume that Bruegel crossed the Alpine mountains during his outward journey. This is at least peculiar since neither Van Mander's citation, nor Bruegel's drawings created during his voyage plead for such an early dating of the Alpine trip. For instance, the Louvre Mountain Landscape (1553) is often regarded as evidence for the artist's presence in the Alpine region (fig. 9)..$^{\circ}$ The same accounts for the so-called Alpine Landscape, also dated c. 1553 and in the aforementioned collection of the Louvre. ${ }^{71}$ In my opinion, these landscapes do not necessarily testify to Bruegel's presence in the Alps. The first traceable manifestation of the artist's fascination with such mountains is only apparent from 1555 onwards, starting in the print series of the Great Landscapes (I555-1556), thus after the artist's return to Antwerp in I554-I555. Moreover, this is supported by Van Mander who tells us that it was only after Bruegel returned home, he spat the impressions (he had swallowed when travelling through the Alps) out again onto canvases and panels.

No sketches are known that were actually made during his voyage through the Alps but it is without doubt that Bruegel must have made them and later used these to assemble his magnificent mountain landscapes. When we compare some of the Great Landscapes etchings and the Great Alpine Landscape (c. 1555-1556) with the early drawings, the difference is striking. An additional argument is that when Bruegel integrated mountainous landscapes in his drawings, prints or paintings from 1555-1556 onwards, they are often conceived of in a more magnificent and large-scale manner compared to the drawings prior to his return to Antwerp. In my point of view the drawings Bruegel made during the period I552-1553 do not contain references to his Alpine experience which suggests, since the journey through the Alps had such an overwhelming effect on his conception and rendering of natural landscapes, these drawings were made before the artist's passage through the Alps. Moreover, some of the early drawings suggest the artist's presence in southern France. Earlier in this essay I demonstrated that the architecture in Southern Cloister in a Valley bears remarkable similarities with the Romanesque 


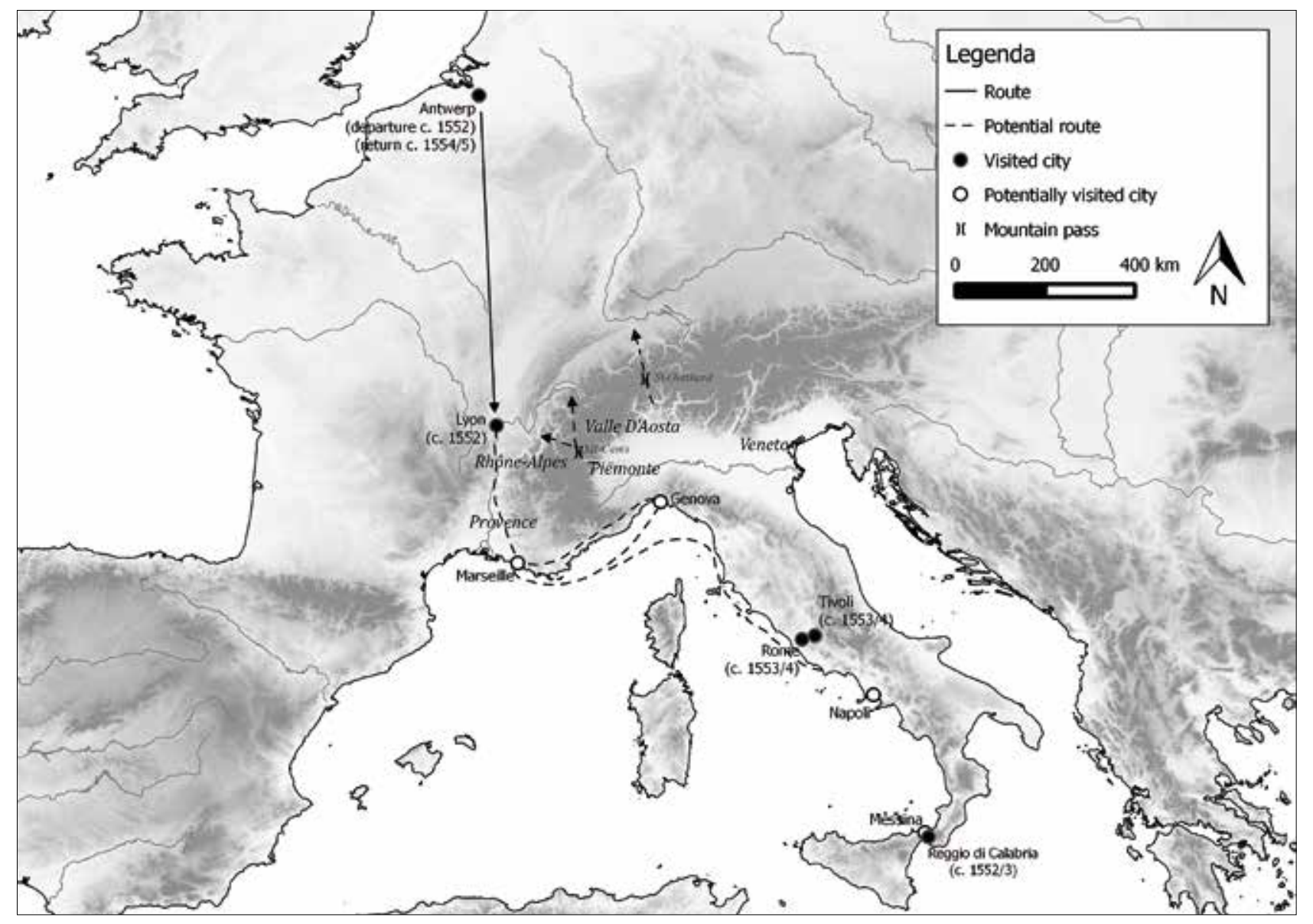

II

Map with (potential) routes of Pieter Bruegel's journey. style typical for the region Provence. This leads us to suggest that Bruegel must have made his passage through the Alps on his way home. As mentioned before, this hypothesis was already put forward during the nineteenth century by Hymans. More recently, Munz made a similar observation.

The exact route the artist must have followed during his Alpine passage is again difficult to establish. There were some standard routes and several authors suggest that he would have passed the Col du Mont Cenis, since this was one of the less heavy and more popular routes (fig. II). $7^{2}$ A quotation in Pieter Paul Rubens's 1640 inventory suggests that Bruegel also crossed the Gotthard Pass: 'Mount Saint-Gotthard by Bruegel the Elder' ('Den Berg Sint-Godard door den Ouden Bruegel'). ${ }^{73}$ The work is also mentioned in the inventory of the Antwerp art dealer Peeter Stevens. In his copy of Van Mander's Schilder-boeck, Stevens made several annotations and among his own possessions he listed a 'View on Saint-Gotthard, painted by Bruegel in 1563 , very pretty and well-known by art lovers' ('Gezicht op de Sint-Gotthard, geschilderd door Bruegel in 1563 , seer curieux, vande liefhebbers wel bekent'). ${ }^{74}$ Since the painting is now lost, it is not possible to find out whether it was a topographical representation or not but the references from both Rubens and Stevens (who stresses the fact that the piece is well known by the art lovers of the time) suggests that the subject must have been recognized as such. Most probably, Bruegel based his painting on sketches he made during his journey. Besides the citation of Van Mander mentioned earlier, the author also refers to Bruegel and the Alps in his Grondt der edel vry schilder-const. It concerns a passage in which he explains how a painter was best to paint mountains and more specific the Alps:

'I can commend Brueghel's paintings and prints, which are wonderfully lifelike and in which he demonstrates how to draw views such as this in the rugged, craggy Alps, gazing down into vertiginous valleys with precipitous rocks, pine trees reaching to kiss the clouds, distant vistas and murmuring streams ${ }^{75}$ 
Van Mander's recommendation of Bruegel as a reference in depicting mountain views is significant. The account again stresses the strong connection between the artist and the Alpine mountains and it demonstrates Bruegel's established reputation as a specialist in depicting mountainous landscapes. This reputation persisted throughout the following century, as Edward Norgate's quotation demonstrates. Additionally, Van Mander's passage suggests the existence of works now lost attesting to the artist's experiences. The author explicitly refers to 'Bruegel's paintings and prints', suggesting that besides the series of the Large Landscapes and the Large Alpine Landscape there must have existed several paintings (and prints?) in which the artist's impressions of the Alps were explicitly apparent for contemporary viewers. In the currently known Bruegel oeuvre, there are several painted works where one can discern the influence of the artist's trip through the Alps, such as The Suicide of Saul in the Battle against the Philistines at Gilboa (I562) and The Conversion of Saul (1567, fig. 10). ${ }^{6}$ However, these paintings do not explicitly refer to the Alpine mountain landscape and the View on St. Gotthard mentioned in Rubens' and Peeter Stevens' inventories, attests the existence of now lost works depicting Alpine landscapes. It is without doubt that apart from this painting many more works (albeit painted, drawn, etched or engraved) by Bruegel have not survived the perils of time. Concerning his travelling route through the Alps, we must conclude that apart from the painting with View on St. Gotthard and the general characteristics in Bruegel's landscapes from 1555-1556 onwards, there is no determining evidence for the paths he may have followed or the places he may have visited (fig. II).

The importance of Bruegel's journey to Italy has long been acknowledged. The vast and versatile landscapes he encountered during the journey were determining for his landscape conception, the development of his distinctive realistic rendering of nature and for his artistic development in general. Moreover, the confrontation with the mountain landscapes during his Alpine experience was to remain an inexhaustible source of inspiration. A precise investigation of Bruegel's work in relation to his voyage combined with a critical reevaluation of the specialist literature provides new information on the initial route followed by the artist and his possible companions. Moreover, it allows us to question the hitherto accepted premise that Bruegel made his passage through the Alps during his onward journey. Based on the thorough analysis of the early works and the mentioned circumstantial evidence, the artist's early presence in the south east of France in I552-1553 is most likely. It was already demonstrated that the premise the artist passed the Alpine region during his onward journey was based on false grounds. In our opinion, this passage only took place after Bruegel's visit to the peninsula and during his return to Antwerp, providing a date c. I554-I555.

\section{NOTES}

* This article is based on chapter IV of my dissertation: Bruegel, the City and the Landscape: Representations of Urban Landscape in the Oeuvre of Pieter Bruegel the Elder, Ghent University 2014. I would like to thank the FWO Vlaanderen (Fund for Scientific Research Flanders) for the grant that made my doctoral research possible. I would also like to express my gratitude to Jan Dumolyn, Koenraad Jonckheere, Maximiliaan Martens and Manfred Sellink fort heir comments and advice during the preparation of this article.

I The term does not only designate Netherlandish artists travelling to Italy but also from the western part of Germany.

2 J. Sterk, Philips van Bourgondië (1465-1524), bisschop van Utrecht alsprotagonist van de Renaissance: zijn leven en maecenaat, Zutphen 1980, pp. 19-22, 99-102, 127-129;
S. Schrader, 'Drawing for Diplomacy: Gossart's Sojourn in Rome', in: M.W. Ainsworth (ed.), exh. cat. Man, Myth and Sensual Pleasure: Jan Gossart's Renaissance, New York (The Metropolitan Museum of Art) 2011, pp. 57-68.

Although this influence was initially restricted to the elite society centered at the court of Philip of Burgundy, Gossart's general interest in classical antiquity and in recent developments in Italian art was decisive for the introduction of the classical idiom into the Netherlandish canon.

4 'per apprendere la maniera italiana' G. Vasari, Le vite de più eccellenti 
architetti, pittori et scultori italiani, da Cimabue insino a' tempi nostri, L. Bellosi and A. Rossi (eds.), Turin I986, p. 384 .

5 An exception is to be found in Bruegel's versions of the Tower of Babel in which both buildings are directly inspired by the Roman Colosseum.

6 For example his indebtedness to Venetian landscape drawings (Titian and Domenico Campagnola) as well as his relying on Italianate idioms for the monumental peasant figures in his later work. See: F. Grossmann, 'Bruegel's Verhältnis zu Raffael und zur Raffael Nachfolge', Festschrift für Kurt Badt, Berlin 1961, pp. I35-I43; K. Arndt, 'Pieter Bruegel d. Ä. und die Geschichte des Waltlandschaft', Jahrbuch Berliner Museen I4

(1972), pp. 96-121; C.

Stridbeck,'Bruegel und der

Niederländische Romanismus', in: Bruegel Studien, Soest 1977; J. ten Brink Goldsmith, 'Pieter Bruegel the Elder and the Matter of Italy', Sixteenth Century Journal 23 (1992), pp. 205-234; G. Volker Grimm, Pieter Bruegel d. A., Italian und die Antike, Göttingen 2009;

T.M. Richardson, Pieter Bruegel the

Elder: Art Discourse in the

Sixteenth-Century Netherlands,

Burlington 20II, pp. 6-7, I4, 3I, $34-38,48-50$, 190

7 The guild year ran from is Octobe I5SI to mid-October of the following year.

8 A. Brilli, Le voyage d'Italie: histoire d'une grande tradition culturelle du XVIe au XIXe siècle, Paris 1989 pp. IIo-ri4; N. Büttner, "Quid siculas sequeris per mille pericula terras?" Ein Beitrag zur Biographie Pieter Bruegels d. Ä. und zur Kulturgeschichte der niederländischen Italienreise', Marburger Jahrbuch für Kunstwissenschaft 27 (2000), pp. 2I2, 214 (notes 44, 45).

9 A. Frank-Van Westrienen, De groot tour. Tekening van een educatiereis der Nederlanders in de zeventiende eeuw, Amsterdam 1983, p. I25; D. Vautier, Alle wegen leiden naar Rome. Kunstenaarsreizen in Europa (I6de - Igde eeuw), Antwerp 2007, pp. I8-i9.

Io A.E. Popham, 'Abraham Ortelius and Pieter Bruegel', The Burlington Magazine 59 (1931), p. I88; F. Grossman, Bruegel: The Paintings. Complete Edition, London I955; M. Sellink, Bruegel. The Complete Paintings, Drawings and Prints, Ghent 2007, p. I3; L. Silver, Pieter Bruegel, New York, London $201 \mathrm{I}$ p. 42.

II K. Kilinski II, 'Bruegel on Icarus: Inversion of the Fall', Zeitschrift für
I2 It is likely that Coecke even travelled a second time to Italy in I535-1536, see: A. Born, 'Pieter Coecke van Aelst and the road leading to Rome', in: Nord/Sud: 2. Ricezioni fiamminghe al di qua della Alpi / Ricezioni italiane al di là delle Alpi. Atti del convegno internazionale a cura di A. De Floriani e $M$. Clelia Galassi (Padova 25-27 ottobre 2007), Milan 2008, pp. 96-107.

I3 On Mayken Verhulst see: A. Monballieu, 'De kunstenaarsfamilie Verhulst Bessemeers', Handelingen van de Koninklijke Kring voor Oudheidkunde, Letteren en Kunst van Mechelen (1974), pp. I05-I2 I; J. Op de Beeck, Mayken Verhulst (I5I8-I599). De Turkse manieren van een artistieke dame, Malines 2005.

I4 'Hy heeft de Const gheleert by Pieter Koeck van Aelst...Hy is van hier gaen wercken by Ieroon Kock, en is voorts ghereyst in Vranckrijck, en van daer in Italien', K. van Mander, Schilder-Boeck, Haarlem I604, fol. 233v.

Is N.E. Serebrennikov, 'Plotting imperial campaigns: Hieronymus Cock's abortive foray into chorography', Nederlands Kunsthistorisch Jaarboek 52 (200I), pp. I87-215; Sellink 2007 (note Io), p. I3.

I6 Investigating documentary, 'topographical' representations requires a critical, pertinent methodology that takes into account the specific characteristics of the medium as well as the original intentions of the artist and the particular circumstances in which the drawing was created. The methodological problems one encounters when identifying localities are extensively discussed in chapter 2 of the forthcoming dissertation (see note i). For the specific problem of Bruegel's studies from nature, see also: F. Grossmann, 'The Drawings of Pieter Bruegel the Elder in the Museum Boymans', Bulletin Museum Boymans 5 (1954), pp. 76-85; P. Schatborn, 'La naissance du paysage naturaliste aux Pays-Bas et l'influence de la topographie aux environs de 1600 ', in: C. Legrand, J.-F. Méjanès, Le paysage en Europe du XVIe au XVIIIe siecle. Actes du Colloque organize au Musée du Louvre par le Service Culturel du 25 au 27 janvier 19go), Paris 1994, pp. 47-95.

I7 For a general description of travel conditions during the sixteenth and seventeenth century, see: Frank-van Westrienen 1983 (note 9), pp. 99-Io5; A. Maczak, Travel in Early Modern Europe, Cambridge I995; A. Babeau, Les voyageurs en France depuis la Renaissance jusqu'à la Révolution, Paris 1999 (first ed. I885).

I8 The inventory attached to Clovio's will refers to a 'quadretto di miniature la metà fatto per mano sua [Clovio's] l'altra di Mo Pietro Brugolo'. Clovio's inventory was first published by Bertolotti: A. Bertolotti, Giulio Clovio principe dei miniatori, Modena 1882 pp. II-I2, I8.

I9 Although the exact location of the encounter between Bruegel and Clovio is not entirely sure, most specialists are convinced they met in Rome. Archival documents confirm Clovio's presence in Florence in 1552 and 1553 . His stay in the city is documented until November 1553. The following document merely dates from 1556 We know that Bruegel was in Rome in 1553-1554 (see pp. 8-9) so it is perfectly plausible that both artists met in Rome. On Clovio see: Ph. Costamagna, 'À propos du séjour florentin de Giulio Clovio (I498-I578)', in: Kunst des Cinquecento in der Toskana (Italianische Forschungen herausgegeben vom Kunsthistorischen Institut in Florenz 3, vol. 17), Munich 1992, pp. 168-175.

20 Ibidem; D. Allart, 'Heeft Pieter Brueghel de Jonge de schilderijen van zijn vader kunnen bestuderen? Methodologische en kritische beschouwingen', in: P. van den Brink (ed.), De Firma Brueghel, Maastricht 2002, p. 48.

2 I G. Reverdy, Atlas historique des routes de France, Paris 1986, p. II and further; M.T. Caracciolo, 'Le voyage à Rome du temps des 'fiamminghi': la route française et l'étape à Lyon', in: Fiamminghi a Roma I508-1608 (Atti del convegno internazionale, Bruxelles 24-25 febbraio 1995), p. 27; G. Reverdy, L'Histoire des routes de France du Moyen Age à la Révolution, Paris 1997.

22 E. Coornaert, Les français et le commerce international à Anvers: fin du XVe-XVIe siècle, 2 volumes, Paris 196I. For the artistic relation between Antwerp and Lyon, see: N. Zemon Davis, 'Le milieu social de Corneille de la Haye (Lyon 1533-1575)', Revue de l'art 47 (1980), pp. 2I-22; D. Ternois, 'Peintres et dessinateurs néerlandais à Lyon du XVIème au XVIIIème siècle. Rapport de mission aux Pays-Bas', Travaux de l'Institut d'Histoire de l'art de Lyon 2 (1976), pp. 25-68.

23 L. Münz, Bruegel: The Drawings. Complete Edition, London $196 \mathrm{I}$, p. 25; K. Oberhuber, 'Bruegel's Early Landscape Drawings,' Master Drawings i9 (198I), p. I50; W. Gibson, Mirror of the Earth. The World Landscape in Sixteenth- 
Century Flemish Painting, Princeton (N. J.) I989, p. 62; M. Sellink, Pieter Bruegel de Oude, Meestertekenaar, Rotterdam $200 \mathrm{I}$, p. 23.

24 Staatliche Museen zu Berlin, Kupferstichkabinett, inv. no. KdZ 5537. H. Mielke, Pieter Bruegel: Die Zeichnungen (Pictura Nova: Studies in I 6 th and I th Century Flemish Painting and Drawing, 2. (eds. H. Vlieghe and K. Van der Stighelen), Turnhout 1996, cat. 2.

25 The central scene was sketched ad vivum whereas the foreground was later reworked in the studio. This implies that the sheet is actually a carefully assembled and compound composition. However, what is of primordial concern is that the central scene, including the landscape and buildings, is a rendering of a topographical site.

26 Büttner 2000 (note 8), p. 216; N. Orenstein (ed.), Pieter Bruegel the Elder. Drawings and Prints, New Haven, Londen 200I, p. 87; Sellink 2007 (note Io), p. 43.

27 Büttner 2000 (note 8), p. 216.

28 Orenstein $200 \mathrm{I}$ (note 26 ), p. 87

29 For the abbeys of Sénanque and Silvacane, see: R. Bérenguier, Abbayes de Provence, Paris 1960 C. Fleischhauer, Die Baukunst der Zisterzienser in der Provence: Sénanque, Le Thoronet, Silvacane (Abteilung Architekturgeschichte des Kunsthistorischen Instituts der Universität zu Köln, 77), Cologne 2003. For the Romanesque chapels in this region, see: A. HartmannVirnich, J. Mathur, Églises et chapelles romanes de Provence, Paris 200I.

30 The late Hans Mielke already suggested that the drawing could have been made in southern France, see: Mielke 1996 (note 24), p. 6

3I I would like to thank Hans Blomme for drawing the map accompanying this article (fig. II)

32 M.T. Caracciolo, 'Le voyage à Rome du temps des "fiamminghi": la route française et l'étappe à Lyon', in: Fiamminghi a Roma 1508-1608, 1995 (note 2I), a. s. to Bollettino d'Arte 100 (1997), pp. 25-26; L. Schudt, Italienreisen im 17 . und 18. Jahrhundert, Munich 1959, p. 156; Frank-Van Westrienen 1983 (note 9), p. 92 and further.

33 F. Moreau and M. Tetel, Jean Tarde. À la rencontre de Galilée, deux voyages en Italie, Geneva 1984, p. 58.

34 E. Norgate, Miniatura or the Art of Limning (1650), M. Hardie (ed.), Oxford 1919, pp. 43-44.
35 G.W. Menzel, Pieter Bruegel der Altere, Leipzig 1966, p. 27.

36 There existed regular services between Marseille and Genova and from there on to Livorno and back.

37 Frank-Van Westrienen 1983 (note 9), p. 92.

38 On the different modes of transport, see: W. Sombart, 'Das europaïsche Wirtschaftsleben im Zeitalter der Frühkapitalismus vornehmlich im I6., 17. und I8. Jahrhundert', in: Idem, Der Moderne Kapitalismus, Leipzig 1928, vol. 2, pp. 259-269; Vautier 2007 (noot 9), pp. 2I-6I.

39 M. Roques, Les apports néerlandais dans la peinture du Sud-Est de la France XIVe, XVe et XVIe siècles, Paris 1961, pp. 190-192; E. Parma, 'Genua, de poort naar het Zuiden' in: T.-H. Borchert (ed.), exh. cat. De eeuw van Van Eyck: De Vlaamse Primitieven en het Zuiden (I430I530), Brugge (Groeningemuseum) 2002, pp. 94-107. The numerous art treasures in Ligurian churches, museums and private collections still bear witness to this rich cultural exchange, see: M. Fontana Amoretti and M. Plomp, Repertory of Dutch and Flemish Paintings in Italian Public Collections (ed. B.W. Meijer), vol. I, Liguria, Florence 1998; C. Cavelli Traverso, Primitivi framminghi in Liguria, Recco 2003.

40 Albeit partially since the hunting scene was later added in the studio.

4I Museum Boijmans Van Beuningen, Rotterdam, inv. no. N igi. The drawing was worked over by a later artist which dramatically changed its appearance by adding large parts of washes in the foreground and in the upper part. For a brief summary of the attribution problems, see: Mielke 1996 (note 24), cat. 54; M. Sellink in: Orenstein 200 (note 26), pp. 206-207.

42 Menzel 1966 (note 35), p. 27; Exh. cat. Fiamminghi a Roma 1508 . I608. Artistes des Pays-Bas et de la principauté de Liège à Rome à la Renaissance, Brussels (Palais des Beaux-Arts) 1995, p. I15; Büttner 2000 (note 8), p. II2.

43 O. Buyssens, 'De schepen bij Pieter Bruegel de Oude', Mededelingen van de Academie voor Marine van België 8 (1954), pp. 162-166.

44 N. Orenstein and M. Sellink, Pieter Bruegel, The New Hollstein Dutch and Flemish Etchings, Engravings and Woodcuts, Oudekerk aan de IJssel 2006 , cat. 48 .

45 First suggested by Münz 196I (note 23) , cat. 26. An additional argument that the drawing served as immediate design for Huys' print, might again be found in Rubens' inventory. Besides the already mentioned View on St. Gotthard two other works from Bruegel's hand are listed as 'Een gevecht tussen Turken en Christenen' (A battle between Turks and Christians) and 'Een landschap met een brand in tempera' (A landscape with fire in gouache). J. Dénucé, De Antwerpsche 'Konstkamers.' Inventarissen van kunstverzamelingen te Antwerpen in de I6de en I7de eeuwen (Bronnen tot de geschiedenis van de

Vlaamsche kunst), The Hague 1932 , pp. 56-57, no. 212, 213. It is remarkable that both subjects correspond with the events rendered in the View on Reggio Calabria and the Battle in the Straits of Messina. Although this assumption is merely based on speculation, it is tempting to consider these works as sketches treating different aspects of the scene Bruegel might have viewed that were eventually assembled in the 1560 drawing.

46 Sellink 2007 (note I0), pp. 156-157

47 Civitates orbis terrarum 1618 , vol. 6 , fol. 58 .

48 'repertum inter Studia autographa Petri Bruegelii eximii nostrii saeculi pictoris. Ab ipsomet delinearum communicavit Georgius Hoefnagelius. A.I6I7'. Braun and Hogenberg I6I 8, vol. 6, fol. 58 . Mielke mentioned a drawing with a View on the Strait of Messina which he listed as a probable copy after one of Bruegel's sketches. Mielke's observations concerning the authenticity proved to be right since nowadays the drawing is regarded as a copy made around 1600 after one of the countless drawings Bruegel must have made during his travel. The sheet was recently (20II) acquired by the Royal Library of Belgium. See: Mielke 1996 (note 24), cat. I5; J. Van Grieken, "View of the Strait of Messina", a Rediscovered Drawing after Pieter Bruegel the Elder: A New Acquisition for the Print Room of the Royal Library of Belgium, In Monte Atrium 4 (2011) pp. 209-219; M. Sellink,

'The Dating of Pieter Bruegel's Landscape Drawings Reconsidered and a New Discovery', Master Drawings 51:3 (2013), p. 294.

49 Galleria Doria Pamphilj, Rome, inv. no. FC546.

50 For an overview of the different opinions concerning attribution, see: R.H. Marijnissen et al., Bruegel. Het volledige oeuvre, Antwerp 1988, p. 38 I; P. RobertsJones and F. Roberts-Jones, Pieter Bruegel, New York 2002, pp. 326327. For a comprehensive discussion 
of the painting, see: Lichtert 2014 (note ${ }^{*}$ ), chapter IV, pp. 45-48.

5 I L. Schudt, Italienreise im 17. Und I8. Jahrbundert, Vienna 1959, p. 2I and further.

52 H. Mielke, 'Radierer um Bruegel', in: O. Simson et al., Pieter Bruegel und seine Welt. Ein Colloquium veranstaltet vom kunsthistorischen Institut der Freien Universität Berlin und dem Kupferstichkabinett der Staatlichen Museen Stiftung Preussischer Kulturbesitz am 13. und 14. November 1975, Berlin 1979, pp. 69-70.

53 Orenstein and Sellink 2006 (note 44), cat. $\mathrm{A}_{4}$ and $\mathrm{A}_{5}$.

54 Sellink 2007 (note IO), pp. I4-I5.

55 The Duke of Devonshire and the Chatsworth Settlement Trustees, Chatsworth, inv. no. 841. Mielke 1996 (note 24), cat. I4.

56 Sellink 2013 (note 48 ), p. 303.

57 Staatliche Museen zu Berlin, Kupferstichkabinett, inv. no. KdZ 5730. The View of the Ripa Grande is drawn with the same combination of inks and in the same precise manner which is not found in the drawings from Bruegel's Italian period. The Rest on the Flight into Egypt is generally dated c. 1555 -1556 and it had been suggested that it was perhaps an unused design for a print, possibly as part of the series of the Large Landscapes. Moreover, the handwriting of the inscription a rypa in the View of the Ripa Grande drawing closely corresponds with that on the preparatory drawings for prints that we know from 1556 onwards, thus corroborating a date of c. 1556 rather than 1553. See: Orenstein 200I (note 26), pp. II6-117; Sellink 2013 (note 48 ), p. 303.

58 Orenstein 200I (note 26), p. 97.

59 F. Coarelli, Guide archéologique de Rome, Paris 1994, pp. 285-311.

60 Kunsthistorisches Museum, Vienna, inv. no. 1026; Museum Boijmans Van Beuningen, Rotterdam, inv. no. 2443.

6I For the similarities between Bruegel's structures and the Roman amphitheater, see: A. Mansbach, 'Pieter Bruegel's Towers of Babel', Zeitschrift für Kunstgeschichte 45 (1982), pp. 43-56; E. Weiner, The Tower of Babel in Netherlandish Painting, (unpublished doctoral dissertation, Columbia University 1985), pp. 88-90; et al. 1988 (note xlix), pp. 210-2ı8; S. Grieten, 'De iconografie van de Toren van Babel bij Pieter Bruegel: traditie, vernieuwing en navolging', Jaarboek van het Koninklijk Museum voor Schone Kunsten Antwerpen 1988 , pp. 97-136.

62 E. g. Sellink 2007 (note Io), pp. I4-I5. On Clovio, see: G. Gamulin and M. GiononiVisani, Giorgio Clovio: Miniaturist of the Renaissance, London 1993.

63 M. H. Nicolson, Mountain Gloom and Mountain Glory. The Development of the Aesthetics of the Infinite, Ithaca (N. J.) I959; Y. Bellenger, 'Les paysages de montagne? L'évolution des descriptions du début à la fin du XVIème siècle', in: Y. Giraud (ed.), Le paysage à la Renaissance (Actes du Colloque International de Cannes, 1985), Freiburg 1988, pp. I2I-I33.

64 'In zijn reysen heft hy veel ghesichten nae t'leven gheconterfeyt, soo datter gheseyt wort, dat hy in d'Alpes wesende, al die berghen en rotsen had in gheswolgen, en t'huys ghecomen op doecken en Penneelen uytghespogen hadde, soo eyghentlijck con hy te desen en ander deelen de Natuere nae volghen., Van Mander 1604, fol. 233r.

65 K. Oberhuber, 'Pieter Bruegel de Oude als tekenaar', in: Exh. cat. Brueghel, een dynastie van schilders, Brussels (Paleis voor Schone Kunsten) I980, pp. 60-66; Idem, 'Bruegel's Early Landscape Drawings', Master Drawings I9 (198I), pp. 146-156.

66 H. Hymans, 'Pierre Brueghel le Vieux', Gazette des Beaux Arts 3 (I890), p. 370.

67 Ut supra, p. 3.

68 H. Mielke, 'Pieter Bruegel d. Ä. Probleme seines zeichnerischen Oeuvres', Jahrbuch der Berliner Museen 33 (1991), pp. 129-I34; H. Mielke, 'Noch einmal zum Problem von Pieter Bruegels Landschaftszeichnungen: Eigene Studien oder Ableitungen?', Münchner Jahrbuch der bildende Kunst 42 (I991), pp. 137-I 47.

69 M. Royalton-Kisch, 'Review of H. Mielke, Pieter Bruegel. Die Zeichnungen', Burlington Magazine I40 (1998), p. 208, note 3.

70 Museum Boijmans Van Beuningen, Rotterdam, inv. no. $\mathrm{N}_{14}$ 6. E.g. Marijnissen, Mielke and Orenstein designate the drawing as Alpine Landscape. Marijnissen et al. (note 50), p. 63; Mielke 1996 (note 24), cat. 16; Orenstein 200I (note 26), cat. I2.

7 I Musée du Louvre, Paris, Département des Arts Graphiques, inv. no. 20.720. Mielke (note 24), cat. 24.
72 W. Gibson, 'La glorification de la montagne: le paysage alpestre dans l'art de Pieter Bruegel l'Ancien', in: La montagne et ses images du peintre d'Akrésilas à Thomas Cole (Actes du ir e congress national des societies savants, Chambéry 1991), Paris I99I, p. I8I.

73 E. Duverger, Antwerpse kunstinventarissen uit de zeventiende eeuw, Brussels i984, vol. 4, p. 297, no. I92.

74 J. Briels, 'Amator Pictoriae Artis. De Antwerpse kunsthandelaar Peeter Stevens (I590-I668) en zijn Constkamer', Jaarboek van het Koninklijk Museum voor Schone Kunsten Antwerpen 1980, pp. 139-226, esp. pp. 194-20I.

75 'Neffens dese mocht ik noch rommen trootsich, op de welverwigh' en constighe stellingh der stucken, en printen van Brueghel bootsich daer hy, als in de hoornigh' Alpes rootsich, ons leert te maken, sonder groote quellingh het diep afsien in een swijmende dellingh, steyle clippen, wolck-cussende pijnbomen, verre verschietens, en ruysschende stroomen.' (Naast deze zou ik nog, als gold het een wedstrijd, kunnen roemen op de welgekleurde en kunstige compositie van de schilderijen en prenten van Brueghel, die er zo natuurlijk uitzien en waarin hij ons leert, zonder grote moeite uit te beelden, zoals in de hoekige, rotsachtige Alpen, het diepe neerkijken in een duizelingwekkende vallei, steile rotsen, pijnbomen die de wolken kussen, verre verschieten en ruisende stromen), K. van Mander, Den grondt der edel vry schilderconst, facsimile, vertaling en annotaties door $H$. Miedema, H. Miedema (ed.), Utrecht 1973 , vol I, p. 210.

76 Kunsthistorisches Museum, Vienna, inv. no. IoII, inv. no. 3690 